\title{
Kesehatan Mental dan Strategi Koping Dalam Perspektif Budaya: Sebuah Studi Sosiodemografi di Kampung Aminweri
}

\author{
Chintya M.G Manullang \\ Program Studi Ilmu Keperawatan, Fakultas Kedokteran dan Ilmu Kesehatan \\ Universitas Kristen Satya Wacana \\ manullangchintya@gmail.com \\ Yulius Yusak Ranimpi \\ Fakultas Teologi, Universitas Kristen Satya Wacana \\ yulius.ranimpi@uksw.edu \\ Rama Tulus Pilakoannu \\ Fakultas Teologi, Universitas Kristen Satya Wacana \\ ramatulus.pilakoannu@staff.uksw.edu
}

\begin{abstract}
Mental health is a state of a person who does not experience the feeling of guilt towards him/herself, have a realistic estimate, can receive a deficiency or weakness, the capability of facing the problems and have satisfaction and happiness in his/her life. The prevalence of severe psychiatric in Indonesia experienced a significant increase in the year 2013 only $1.7 \%$ to $7 \%$ in the year 2018. In mental health, cultural factors also play an important role. A person is said to be healthy or mentally ill depends on culture. There are two types of coping according to Lazarus and Folkmannamely problem focused coping (PFC) and emotion focus coping (EFC). In the PFC, the individual in dealing with the problem would be the logical thinking and trying to solve the problems of the positive. Whereas in the EFC, individuals assuage the emotions evoked by the stressor (source of stress) without trying to change the situation. Describe the mental health and cultural perspectives in coping strategy based on the profile of the sociodemographic community in Aminweri village. A qualitative approach to data collection techniques as well as phenomenology with structured interviews and documentation. Determination of the participant determined by purposive sampling technique. Obtained 3 huge themes: acquired memory, emotion regulation strategies and coping. Generally variable sociodemographic connectedness with a decline in memory, emotion regulation, shared the coping community Aminweri Village and there is the influence of the culture of Biak.
\end{abstract}

Keywords: mental health; coping strategy; sociodemographic. 


\begin{abstract}
Abstrak
Kesehatan mental adalah suatu keadaan seseorang tidak mengalami perasaan bersalah terhadap diri sendiri, memiliki estimasi yang realistis, dapat menerima kekurangan atau kelemahannya, kemampuan menghadapi masalah-masalah serta memiliki kepuasan dan kebahagiaan dalam hidupnya. Prevalensi gangguan jiwa berat di Indonesia mengalami peningkatan yang cukup signifikan, yaitu tahun 2013 hanya $1,7 \%$ menjadi $7 \%$ di tahun 2018. Dalam kesehatan mental, faktor kebudayaan juga memegang peran penting. Seseorang itu dikatakan sehat atau sakit mental bergantung pada kebudayaannya.Terdapat dua jenis koping menurut Lazarus dan Folkman, yaitu problem focus coping (PFC) dan emotion focus coping (EFC). Dalam PFC, individu dalam menangani masalahnya akan berfikir logis dan berusaha memecahkan permasalahan dengan positif. Sedangkan dalam EFC, individu meredakan emosi yang ditimbulkan oleh stressor (sumber stres) tanpa berusaha mengubah situasi. Tujuan dari penelitian adalah mendeskripsikan kesehatan mental dan strategi koping dalam perspektif budaya berdasarkan profil sosiodemografi masyarakat di kampung Aminweri. Metodologi yang digunakan adalah kualitatif dengan pendekatan fenomenologi serta teknik pengumpulan data dengan wawancara terstruktur dan dokumentasi berupa foto. Penentuan partisipan ditentukan dengan teknik purposive sampling. Hasil yang diperoleh didapatkan 3 tema besar: daya ingat, regulasi emosi dan strategi koping.Kesimpulan secara umum variabel sosiodemografi memiliki keterkaitan dengan penurunan daya ingat, regulasi emosi, stategi koping masyarakat Kampung Aminweri serta terdapat pengaruh budaya Biak.
\end{abstract}

Kata kunci: kesehatan mental; strategi koping; sosiodemografi.

\title{
Pendahuluan
}

Kesehatan mental adalah suatu keadaan seseorang tidak mengalami perasaan bersalah terhadap diri sendiri, memiliki estimasi yang realistis, dapat menerima kekurangan atau kelemahannya, kemampuan menghadapi masalahmasalah serta memiliki kepuasan dan kebahagiaan dalam hidupnya (Putri et al., 2012). Secara global prevalensi gangguan jiwa diperkirakan mengalami peningkatan sekitar 450 juta jiwa, serta terjadi di negara berkembang salah satunya, yaitu Indonesia (Badan Penelitian dan Pengembangan Kesehatan, 2013). Prevalensi gangguan jiwa berat di Indonesia mengalami peningkatan yang cukup signifikan yaitu tahun 2013 hanya 1,7\% menjadi 7\% di tahun 2018 (Badan Penelitian dan Pengembangan Kesehatan, 2018). 
Dalam kesehatan mental, faktor kebudayaan juga memegang peran penting. Seseorang itu dikatakan sehat atau sakit mental bergantung pada kebudayaannya (Hamdi et al., 2007). Pandangan ini bermakna bahwa pada suatu budaya tertentu, konsep kesehatan mental hendaknya dipahami dalam konteks budaya tersebut. Sistem nilai yang fragmental dan kontekstual tentunya akan memberi pemaknaan yang khas terhadap konsep apapun, termasuk konsep kesehatan mental. Impilkasi praktisnya dalam pemahaman Hamdi dan Muniarti (2007) adalah bahwa kebudayaan memunya sifat yang statis dan oleh karena itu hal yang boleh dilakukan dalam suatu budaya tertentu, bisa menjadi sesuatu yang aneh dan tidak normal dalam budaya lain, dan sebaliknya juga. Kondisi yang demikian itu akan menghasilkan pandangan atau persepsi yang berbeda tentang suatu pengertian yang sama dan tidak sama dalam konteks penyakit, sehat, dan sakit (Dumatubun, 2002)

Secara konseptual sakit dilihat secara "etik" yang dikutip dari Djekky, yaitu penyakit (disease) dan sakit (illness) (dalam Dumatubun, 2002). Sedangkan secara "emik" sakit dapat dilihat berdasarkan pemahaman konsep kebudayaan masyarakat penyandang kebudayaan itu sendiri, sebagaimana dikemukakan oleh Foster dan Anderson menemukan konsep penyakit (disease) masyarakat non-barat dibagi atas dua kategori umum, yaitu personalistik dan naturalistik (dalam Dumatubun, 2002). Oleh sebab itu, diperlukan suatu bentuk pertahanan diri dalam menghadapi masalah. Hal ini dikenal dengan istilah strategi koping yang bertujuan mengatasi perubahan yang dihadapi atau beban yang diterima. Menurut Yani, koping adalah perilaku yang terlihat dan tersembunyi yang dilakukan seseorang untuk mengurangi atau menghilangkan ketegangan psikologi dalam kondisi yang penuh stres (dalam Siti, 2017). Terdapat dua jenis koping menurut Lazarus dan Folkman yaitu problem focus coping (PFC) dan emotion focus coping (EFC). Dalam PFC, individu dalam menangani masalahnya akan berfikir logis dan berusaha memecahkan permasalahan dengan positif. Sedangkan dalam EFC, individu meredakan emosi yang ditimbulkan oleh stressor (sumber stres) tanpa berusaha mengubah situasi (dalam Saputra, Ranimpi, \& Pilakoannu, 2018; Tri, 2012). Dengan demikian kesehatan mental dan strategi koping mengacu pada hal 
yang sama yaitu kemampuan seseorang dalam beradaptasi atau menghadapi suatu masalah. Beberapa hal yang turut mempengaruhi kesehatan mental dan pemilihan strategi seseorang yaitu dilihat dari segi sosial (pendidikan dan pekerjaan) dan demografi (usia, jenis kelamin, agama, kelahiran, kematian dan perkawinan) (Idaiani et al., 2009).

Berdasarkan jurnal Antropologi Papua, masyarakat suku Biak mengkonsepsikan penyakit sebagai hal yang menyebabkan terjadinya ketidakseimbangan dalam tubuh seseorang (Dumatubun, 2002). Hal ini berarti adanya kekuatan yang diberikan oleh seseorang melalui kekuatan gaib karena rasa dengki (Dumatubun, 2002). Watak orang Papua dikenal keras dalam menghadapi suatu masalah dan turut menentukan seseorang untuk memilih jenis strategi koping yang akan digunakan. Selain itu, komponen sosiodemografi juga turut dalam membentuk dan menentukan jenis strategi koping yang akan digunakan. Sosiodemografi berasal dari dua kata, yaitu sosial dan demografi. Sosial adalah salah satu komponen variabel non-demografi, seperti pendidikan, pekerjaan, dan lain-lain, sedangkan demografi adalah suatu ilmu yang mempelajari penduduk di suatu wilayah terutama mengenai jumlah, struktur (usia, jenis kelamin, dan agama), dan proses perubahannya (status perkawinan) (Suardana, 2011). Oleh sebab itu, maka peneliti melakukan penelitian ini dengan tujuan untuk mendeskripsikan kesehatan mental dan strategi koping dalam perspektif budaya berdasarkan profil sosiodemografi masyarakat di kampung Aminweri.

\section{Metode}

Metode penelitian ialah kualitatif dengan pendekatan fenomenologi yang dilakukan selama 3 bulan di Kampung Aminweri, Kabupaten Supiori, Distrik Supiori Timur, Provinsi Papua. Teknik pengumpulan data dengan wawancara terstruktur dan dokumentasi berupa foto. Jumlah partisipan 10 orang yang ditentukan dengan teknik purposive sampling. Kriteria partisipan, yaitu orang dewasa laki-laki dan perempuan umur $\geq 18$ tahun, bisa baca dan menulis, dan mampu berkomunikasi dalam bahasa Indonesia. Uji validasi dengan memakai Triangulasi Sumber (Bachri, 2010) yang dilakukan pada orang terdekat partisipan 
(keluarga, tetangga). Data dianalisa dengan menggunakan teknik Miles and Huberman, yaitu pengumpulan data, reduksi data, kemudian disajikan dan penarikan kesimpulan (Novitasari, 2014).

\section{Hasil dan Pembahasan}

Berdasarkan hasil analisa data, maka dalam penelitian ini terdapat dua kategori utama, yaitu: kesehatan mental (daya ingat, regulasi emosi) dan strategi koping (problem focus coping dan emotional focus). Berikut adalah deskripsi dari masing-masing kategori.

\section{Identitas partisipan}

Total partisipan dalam penelitian ini adalah 10 orang, yang terdiri dari 5 orang laki-laki dan 5 orang perempuan. Seluruh partisipan beragama Kristen. Untuk status perkawinan, 8 orang telah menikah dan 2 sisanya belum menikah. Berdasarkan status pekerjaan cukup beragam, mulai pelajar, pegawai negeri sipil, ibu rumah tangga, petani, wirausaha hingga pensiunan. Sedangkan berdasarkan usia partisipan terentang dari 18 tahun hingga 68 tahun. Berikut adalah tabel yang berisi identitas partisipan yang berpartisipasi dalam penelitian ini.

Tabel 1. Karakteristik Partisipan Berdasarkan Sosiodemografi

\begin{tabular}{llllll}
\hline & Umur & Jenis kelamin & Agama & Status perkawinan & Pekerjaan \\
\hline P1 & 68 Tahun & Laki - laki & Kristen protestan & $\begin{array}{l}\text { Menikah } \\
\text { Belum menikah }\end{array}$ & $\begin{array}{l}\text { Pensiunan } \\
\text { Tidak } \\
\text { bekerja }\end{array}$ \\
P2 & 18 Tahun & Laki - laki & Kristen protestan & Menikah & Wiraswasta \\
P3 & 49 Tahun & Laki - laki & Kristen protestan & Belum menikah & $\begin{array}{l}\text { Tidak } \\
\text { bekerja }\end{array}$ \\
P4 & 19 Tahun & Perempuan & Kristen protestan & Menikah & Petani \\
P5 & 68 Tahun & Laki - laki & Kristen protestan & Ibu rumah \\
P6 & 38 Tahun & Perempuan & Kristen protestan & Menikah & $\begin{array}{l}\text { tangga } \\
\text { PNS }\end{array}$ \\
P7 & 54 Tahun & Laki - laki & Kristen protestan & Menikah & $\begin{array}{l}\text { Ibu rumah } \\
\text { tangga }\end{array}$ \\
P8 & 46 Tahun & Perempuan & Kristen protestan & Menikah & Ibu rumah \\
& tangga \\
P9 & 58 Tahun & Perempuan & Kristen protestan & Menikah & $\begin{array}{l}\text { Ibu rumah } \\
\text { tangga }\end{array}$ \\
\hline
\end{tabular}




\section{Kesehatan Mental}

\section{Daya ingat}

Daya ingat adalah kekuatan jiwa manusia untuk menerima, menyimpan, dan merespon tanggapan. Tanpa daya ingat kita tidak bisa mengenal siapa diri kita dan orang lain serta berkomunikasi dengan baik (Dharmawan Triadib, 2015). Dalam konteks jenis kelamin, data World Health Organization (dalam Adipati \& Purwokerto, 2015) mendeskripsikan bahwa persentase perempuan yang mengalami masalah dalam mengingat nama, tempat dan orang lebih besar dibanding laki-laki, yaitu $9,5 \%$ berbanding 5,8\%. Dan, dalam penelitian ini, masalah dalam mengingat nama, tempat dan orang dialami secara khusus oleh partisipan laki-laki yang berusia $>58$ tahun.

Menurut Departemen Kesehatan Republik Indonesia (dalam Suardiman, 2011) bertambahnya umur seseorang ditandai dengan kemunduran kognitif seperti mudah lupa, ingatan tidak berfungsi dengan baik dan lupa nama-nama. Hal ini sesuai dengan hasil penelitian yang dilakukan oleh Rachel dkk (Mongisidi et al., 2012) yaitu bahwa umur yang semakin meningkat mengakibatkan perubahan anatomi, seperti semakin menyusutnya otak sehingga dengan sendirinya bisa menyebabkan terjadinya penurunan fungsi kognitif (Walgito,1986). Dalam penelitian ini, cara partisipan mengatasi masalah mengingat, yaitu dengan berusaha untuk mengingat, merokok, memakan pinang, berinteraksi dan meminta bantuan orang lain. Berikut adalah ungkapan partisipan:

"Saya lupa nama orang, lupa nama tempat" (P5: 5-10)

"Ada yang menceritakan ataupun sementara ada yang bisa mengingat kembali bercerita dan bisa saya ingat kembali" (P1: 35-40)

"Jalan keluar, isap rokok, makan pinang. Yang saya lakukan bisa isap rokok, makan pinang" (P2: 10- 20)

"Mungkin dimakan senja usia sehingga sementara ini saya mengatakan bahwa beberapa persen yang bersifat lupa masih ada sementara ada.Sementara kalau apa yang saya ingat tetapi terjadi kelupaan akan lama baru saya ingat (P1:5- 30)

\section{Regulasi Emosi}

Regulasi emosi adalah usaha untuk mengatur atau mengelola emosi atau bagaimana seseorang mengalami dan mengungkapkan emosi yang dapat mempengaruhi perilaku individu untuk mendapat tujuannya (Silaen \& Dewi, 
2015). Kategori ini membahas tentang aspek emosi dalam hal ini (marah, sedih dan senang). Emosi adalah manifestasi perasaan atau efek keluar dan disertai banyak hal fisiologi, dan biasanya berlangsung tidak lama. Emosi juga diartikan sebagai suatu keadaan perasaan yang telah melampaui batas sehingga untuk menjalin hubungan dengan lingkungannya terganggu. Perasaan merupakan gejala psikis yang memiliki sifat khas subjektif berhubungan dengan persepsi dan dialami sebagai rasa marah, sedih, senang dalam berbagai derajat dan tingkatannya. Setiap orang memiliki intensitas perasaan yang berbeda walaupun menghadapi stimulus yang sama. Kualitas perasaan ditentukan oleh perasaan marah, sedih, senang (Sunaryo, 2004).

a. Konteks yang menyebabkan ekspresi emosi

Budaya Biak dipercayai oleh partisipan sebagai salah satu faktor yang memberi pengaruh dalam mengekspresikan emosi. Berdasarkan jenis kelamin, bagi laki-laki maupun perempuan mengatakan bahwa budaya berpengaruh terhadap ekspresi emosi. Hal ini nampak dalam bentuk pertikaian (konflik), baik secara verbal maupun non-verbal (fisik). Pertikaian secara verbal berupa percekcokan dan pertikaian non-verbal (fisik) berupa perkelahian hingga saling membunuh. Ekspresi emosi seperti di atas terjadi dalam konteks adanya pelanggaran terhadap norma kesusilaan dalam masyarakat. Bentuk penyelesaian masalah yang biasanya dilakukan, yaitu secara adat yang berupa pembayaran denda. Hal ini berkaitan dengan hukum adat yang dikaji dari perspektif asas, norma, teoritis dan praktik dikenal dengan istilah, "hukum yang hidup dalam masyarakat", "living law", "nilai-nilai hukum dan rasa keadilan yang hidup dalam masyarakat", "hukum tidak tertulis", "hukum kebiasaan", dan lain sebagainya (Mulyadi, 2013). Selain itu, apabila seseorang mengucapkan kata-kata kasar (makian) kepada orang lain maka harus meminta maaf dan jika tidak, orang tersebut akan dikutuk mati. Berikut yang disampaikan partisipan:

"Sering terjadi asusila antara marga dengan marga terjadi pertengkaran dari orang kampung ini disitu terjadi pertengkaran baik secara mulut maupun fisik" (P1: 75$80,160-175)$

"Yah, memang mempengaruhi, itu kalo kita marah terhadap orang, saya harus bikin denda ato bayar denda begitu, jadi memang mempengaruhi, karena budaya Biak itu keras"(P9: 70-75) 
"Budaya Biak yang keras mempengaruhi emosinya seperti saling pukul, saling bunuh menggunakan benda tajam, nanti diselesaikan dalam adat"(P6: 60-65)

"Budaya mempengaruhi sehingga walaupun saya emosi sampaikan hal yang tidak berkenan kepada e om, apabila saya tidak minta maaf kepada om saya maka om saya kutuk saya mati karena ini budaya kuat"(P3:160-175)

\section{b. Ekspresi Warna Emosi}

Seseorang yang mengalami emosi, pada umumnya kurang atau tidak dapat menguasai dirinya lagi dan tidak memperhatikan lagi keadaan sekitarnya. Dari penelitian ini, partisipan dengan kriteria tidak bekerja dan berumur $\geq 18$ tahun mengungkapkan bahwa pada saat marah, partisipan menyampaikan kata-kata kasar, memukul orang dan melukai diri sendiri (misalnya, dengan memukul kaca/cermin). Tingkah laku perbuatannya tidak lagi memperlihatkan suatu aturan yang ada dalam masyarakat, tetapi telah memperlihatkan adanya gangguan atau hambatan dalam dirinya. Dengan demikian maka emosi dipandang sebagai perasaan yang secara perlahan lebih besar kekuatannya (Walgito, 1986). Emosi negatif seperti ini dapat menyebabkan munculnya suatu dorongan kekerasan yang dilakukan terhadap orang lain, siksaan verbal dan fisik terhadap anak (King, 2010). Misalnya, partisipan dengan latar belakang sebagai pensiunan memaparkan bahwa melempar barang berupa piring dan memukul anak-anak juga dilakukan pada saat marah. Pengekspresian marah dapat meningkat hingga muncul perdebatan, berteriak, menjerit dan menangis ( Travis 1989, dalam King, 2010). Bagi partisipan yang sudah menikah ekspresi emosi adalah melarikan diri, memilih diam, menghindar, duduk dan menjauh serta merasa sedih.Berikut adalah yang disampaikan partisipan:

"saya melampiaskan kata-kata kotor yang tidak bagus yang tidak berkenan setelah itu saya tinggalkan rumah saya menghindar jauh" (P3: 105-110)

"Memilih untuk diam." (P4: 105-110)

"Ketika tidak mampu mengontrol emosi saya duduk saja." (P7: 20-25)

"Bisa sedih. (P2:50- 55)

"Kalau emosi biasa pukul teman, lempar piring." (P2:65- 70)

"Memilih untuk diam." (P4: 105-110)

"Bisa sedih". (P2:50- 55)

"Menangis paling sering." (P6: 75-80)

"Kalau emosi biasa pukul teman, lempar piring." (P2:65- 70)

"Melukai, biasa tumbuk kaca, memilih melarikan diri karena lari untuk tenangkan diri." (P2: 70- 75) 
Sehubungan dengan durasi untuk meredakan emosi marah, berikut yang partisipan sampaikan:

"Satu jam begitu selesai." (P1: 210-215)

"3 bulan. " ( P5: 70-75)

Partisipan dengan kriteria pekerjaan tidak bekerja yang berumur di bawah 19 tahun melampiaskan rasa sedih dengan berteriak, menyendiri, memukul teman, melukai atau menyakiti diri sendiri (misalnya, dengan memukul kaca/ cermin). Sedangkan partisipan dengan latar belakang pekerjaan ibu rumah tangga memilih untuk meremas sagu, menyalahkan diri sendiri, menghancurkan barang berupa piring, pergi ke kebun dan melarikan diri. Selain itu, partisipan mengatakan bahwa membutuhkan waktu untuk meredakan rasa sedih, bisa dalam hitungan beberapa hari. Berikut ungkapan partisipan:

"Memilih berteriak" (P1: 220-225)

"Iya menyendiri, menyakiti diri sendiri" (P2:85-95)

"ini harus ke dusun, harus ke kebun" (P3: 215-220)"

"Memilih untuk diam." (P4: 105-110)

"Bisa sedih." (P2:50- 55)

"lempar piring." (P2:65- 70)

"Melukai, biasa tumbuk kaca, memilih melarikan diri karena lari untuk tenangkan diri." (P2: 70- 75)

"Mungkin satu minggu begitu." (P4: 110-115)

"Harus tinggalkan rumah ini harus ke kebun. "(P3: 215- 220)

"Melampiaskan kata-kata kotor." (P3 105-110)

"Suka marah marah" (P8: 5ss5-58)

"Menghancurkan piring begitu" (P4 95-10)

Dalam mengekspresikan rasa senang, bagi partisipan yang sudah menikah mengatakan bahwa biasanya melakukan hal-hal seperti menggambar, menonton televisi, bernyanyi, menulis puisi dan lagu serta memainkan alat musik (gitar, suling). Partisipan yang belum menikah juga mengekspresikan rasa senang dengan bermain bola voli dan bernyanyi. Perasaan senang dapat membangun pertemanan, berolahraga serta menciptakan dorongan terhadap orang lain untuk bermain (Cohn \& Fredrickson,2006; Waugh \& Fredrickson, 2006, dalam King, 2010 ). Emosi positif seperti rasa senang dapat berperan sebagai penanda kesejahteraan, didukung oleh beberapa kasus emosi positif dapat melawan serangkaian emosi negatif (Fredikson, 2001, dalam King, 2010). Contohnya sedikit rasa sukacita dan kepuasan hati ditemukan mampu melawan efek emosi 
kardivaskuler dari emosi negatif seperti kesedihan (Fredikson \& Levenson, 1998, dalam King, 2010). Selain itu, partisipan menyampaikan kepada orang lain bahwa dirinya merasa senang dan mengundang teman-teman untuk makan pinang sambil bercerita seadanya. Emosi positif memiliki peran penting untuk adaptasi, pertumbuhan dan hubungan sosial seseorang. Dengan membangun sumber daya seseorang dan sosial, emosi positif meningkatkan kesejahteraan seseorang (King, 2010). Dalam hal ini partisipan mengatakan:

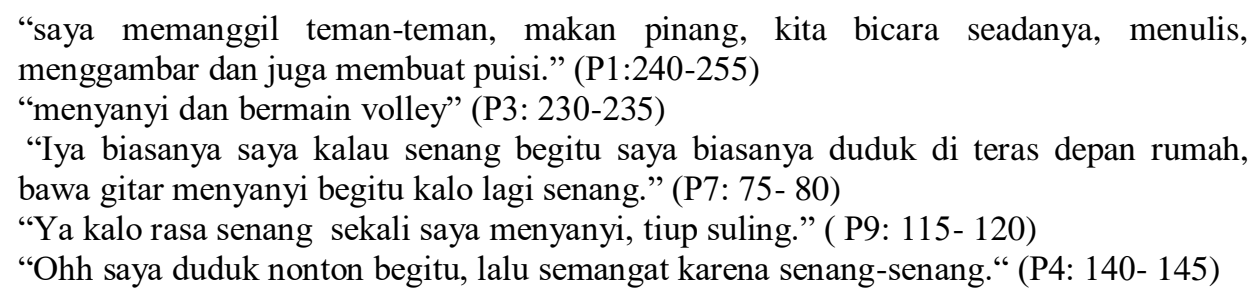

\section{Strategi Koping}

\section{Problem Focus Coping (PFC)}

Andrews mengemukakan bahwa PFC merupakan perilaku koping yang tepat dan efektif, salah satunya adalah dengan mengatasi secara langsung masalah-masalah yang muncul (Bakhtiar \& Asriani, 2015). Berdasarkan jenis kelamin, partisipan perempuan dengan pekerjaan ibu rumah tangga mengatakan bahwa mereka menyelesaikan masalah secara langsung dan meminta maaf secara adat dengan memberikan pinang maupun piring. Ketika seorang perempuan menilai penyebab kekerasan yang menimpa dirinya adalah sesuatu yang berada di luar dirinya, ia akan merasa menjadi korban, dan karenanya ia harus melakukan sesuatu untuk mencoba memecahkan masalahnya secara langsung pada sumber masalah (Nurhayati, 2014). Hal ini sesuai dengan penelitian yang dilakukan oleh Adi bahwa PFC lebih cenderung digunakan oleh jenis kelamin perempuan (Wibawa \& Widiasavitri, 2013). Selanjutnya, penyataan ini didukung oleh hasil wawancara dengan masyarakat asli Biak diketahui bahwa untuk menyelesaikan masalah harus dengan meminta maaf, memberikan denda, pinang, rokok, sirih, maupun kapur.

Khusus mengenai permasalahan asusila/perzinahan biasanya akan diselesaikan secara musyawarah lewat lembaga masyarakat yang disebut kainkain 
kankara mпи. Lembaga ini selain berfungsi sebagai wadah untuk merundingkan segala aktivitas yang menyangkut bidang pemerintahan, dan berfungsi sebagai badan pengadilan yang memutuskan hukuman bagi mereka yang melanggar aturan adat (Mansoben, 2003). Proses penyelesaian masalah akan dihadiri oleh keluarga korban dan keluarga pelaku (kedua belah pihak) dan oknum-oknum yang dipercayakan sebagai pemimpin, yaitu Manawir (ketua adat)sebagai ketua dewan yang membuat keputusan berdasarkan kesepakatan bersama, bukan atas kehendak sendiri (Mansoben, 2003), faker (wakil ketua adat), manfasfas (sekertaris), tongga (pembantu umum) dan marga lain. Proses penyelesaian masalah yaitu; 1) Manawir (ketua adat) memberikan kesempatan berbicara kepada pelaku dan korban. 2) Terjadinya berbedaan pendapat mengakibatkan perdebatan antara pelaku dan korban, 3) Perdebatan dihentikan oleh Manawir (ketua adat) dengan mengetok palu, 4) Penentuan denda berupa uang atau piring, 5) Penawaran denda antara pelaku dan korban. Selanjutnya kedudukan di lembaga kainkain karkara mпи sebagai lembaga pengadilan bertugas untuk menyelesaikan atau memutuskan pembayaran denda karena telah berbuat zina (Mansoben, 2003).

Dalam hal penentuan denda di tentukan oleh pihak perempuan terlebih dahulu dan denda paling banyak biasanya dari pihak laki-laki. Denda dapat diberikan kepada kedua belah pihak apabila keduanya terbukti bersalah. Akan ada penawaran denda antara kedua belah pihak dengan memberikan keringanan sehingga tidak sepenuhnya di bayar dengan uang tetapi bisa juga dengan piring namun tidak mengurangi jumlah denda yang sudah di tentukan. Keputusan yang diambil sesuai dengan kesepakatan bersama dalam forum tersebut (Mansoben, 2003). Jika musyawarah itu tidak di selesaikan maka akan ada perkelahian yang terus menerus terjadi antara marga. Partisipan membutuhkan bantuan orang lain, keluarga dan teman untuk membantunya menyelesaikan masalahnya. Hal ini dilakukan karena partisipan percaya bahwa orang lain, keluarga dan teman dapat membantu menyelesaikan masalahnya dengan baik. Berikut adalah ungkapan partisipan:

“Harus selesaikan secara langsung.” (P8: 195- 200) 


\begin{abstract}
"Menyelesaikan masalah tidak segampang membalik telapak tangan, masalah itu dengan berkumpul bersama untuk menyelesaikan masalah, membutuhkan orang lain untuk menyelesaikan masalah". (P1: 515-525)

"Musayawarah di hadirkan oknum-oknum yang dipercayakan sebagai pemimpin (manannwir), dari marga lain yang tidak bersangkutan untuk menyelesaikan permasalahan itu. Manawir atau kepala adat sebagai pemimpin masalah yang menyangkut ada istiadat dalam sebuah kampung, faker atau wakil pimpinan jika Manawir tidak ada digantikan oleh faker, ada Manfasfas atau sekertaris sebagai membantu Manawir melaksanakan tugasnya sebagai pemimpin adat dalam kampung dan tongga atau pembantu umum hadir sebagai membantu ada hal hal yang pada saat itu dibutuhkan bisa langsung dibantu oleh tongga. Keputusan yang diambil adalah sesuai dengan perbuatan dari pada kedua belah pihak dan pelaku harus menerima hukuman secara denda uang atau piring”. (P1: 570-590)
\end{abstract}

\title{
2. Emotional Focus Coping (EFC)
}

Emotional Focus Coping adalah bentuk koping yang lebih berfokus pada emosi dalam menyelesaikan masalah. Biasanya partisipan meredakan emosi yang ditimbulkan oleh stressor (sumber stres) tanpa berusaha mengubah situasi (Rayanti, Wariunsora, \& Soegijono, 2019; Saputra, Ranimpi, \& Pilakoannu., 2018). Berdasarkan jenis kelamin, bagi partisipan laki-laki lebih memilih menggunakan strategi ini untuk menyelesaikan masalah. Hal ini berbeda dengan penelitian yang dilakukan oleh Oktarisa dan Yusra bahwa EFC lebih cenderung digunakan oleh jenis kelamin perempuan (Oktarisa \& Yusra, 2015). Selanjutnya, partisipan meringankan beban masalah dengan memilih untuk mendekati orang lain yang bisa memberikan pendapat secara rohani dan menyelesaikan masalah. Partisipan juga mengatakan pernah merasa lelah maupun tidak lelah dengan masalah yang menghampiri hidupnya. Dalam hal ini partisipan mengatakan:

"Butuh teman, sahabat begitu bisa selesaikan saya punya masalah.” (P2:175-180)

"Ya biasa begitu, sering lelah kalau ada masalah." (P9: 295-300)

"Meringankan masalah dalam budaya Biak dengan duduk di tempat para-para pinang, makan pinang sambil ngobrol dan cerita.(P1: 820- 830)

"Menyalahkan diri sendiri karena ada infomasi dari orang lain tentang perbuatan anaknya, yang tidak melakukan sesuatu tetapi terlanjur dipukul (rotan/siksa)". (P1: 835840)

"Tindakan menyalahkan orang lain adalah tindakan yang salah karena orang yang sebenarnya benar disalahkan dan orang yang salah dibenarkan." (P1:850-860)

"Sering, senang mencari suatu solusi untuk mempercepat penyelesaian sebuah masalah." (P1: 905-910)

"Biasa lebih sering mencari masalah kepada teman." (P2: 310- 315)

"Iya ikhlas." (P5: 240)

"Ya harus minta maaf." (P10: 215-220)

"biar ringan harus denda." (P9: 310-315)

"Ya ada, ya seperti minum kopi makan pinang, pergi ke pantai, tokok sagu atau kerja di kebun.”(P6: 370- 375) 
Hal-hal yang akan dilakukan partisipan untuk meringankan masalahnya yaitu; duduk di para-para sambil makan pinang, bercerita dan bercanda, merokok dan minum kopi bersama, menokok sagu (proses pembuatan tepung sagu), pergi ke pantai, dan saling meminta maaf. Partisipan pernah menyalahkan diri sendiri atas masalah yang dihadapinya karena tidak mengetahui informasi yang sebenarnya tetapi partisipan terlanjur memukul dan menyiksa anaknya. Sedangkan bagi perempuan yang sudah menikah maupun yang belum menikah mengatakan tidak membantu keluarga, marah terhadap diri sendiri, menyalahkan orang lain terhadap masalah yang dihadapinya dengan alasan bahwa itu adalah jalan yang terbaik baginya. Namun, ada juga partisipan yang sudah menikah mengganggap bahwa menyalahkan orang lain atas masalahnya merupakan tindakan yang tidak manusiawi.

\section{Kesimpulan dan Saran}

\section{Kesimpulan}

Berdasarkan penelitian ini dapat disimpulkan bahwa konteks yang menyebabkan ekspresi emosi bagi partisipan laki-laki maupun perempuan dalam pengaruh budaya Biak, yaitu adanya pertikaian secara verbal dan non verbal. Penyelesaian masalah ini, biasanya dilakukan secara adat, yaitu berupa pembayaran denda. Hal ini berkaitan dengan hukum adat yang dikaji dari perspektif asas, norma, teoretis dan praktik dikenal dengan istilah, "hukum yang hidup dalam masyarakat", "living law", "nilai-nilai hukum dan rasa keadilan yang hidup dalam masyarakat", "hukum tidak tertulis", "hukum kebiasaan", dan lain sebagainya.

Dalam melampiaskan rasa sedih, terdapat partisipan yang biasanya mengekspresikan dengan cara berteriak, menyendiri, memukul teman, melukai atau menyakiti diri sendiri. Sedangkan partisipan yang lainnya memilih untuk bekerja (meremas sagu), menyalahkan diri sendiri, menghancurkan barang, pergi berkebun dan melarikan diri. Selanjutnya, dalam mengekspresikan rasa senang, beberapa partisipan mengatakan biasanya melakukan kegiatan seperti menggambar, menonton televisi, bernyanyi, menulis puisi dan lagu serta 
memainkan alat musik. Sedangkan yang lain mengekspresikan rasa senang dengan bermain bola voli dan bernyanyi.

Dalam hal kemampuan mengingat, partisipan dengan umur $>54$ tahun dan berjenis kelamin laki-laki mengalami masalah dalam hal mengingat nama, tempat dan orang. Hal ini tidak dialami oleh partisipan perempuan. Untuk mengatasi masalah mengingat, partisipan cenderung untuk tetap berusaha mengingat, merokok, memakan pinang, berinteraksi dan meminta bantuan orang lain.

Dalam hal meringankan beban masalah partisipan memilih untuk mendekati orang lain yang bisa memberikan pendapat secara rohani dan menyelesaikan masalah.Partisipan perempuan memilih strategi koping yang lebih berfokus pada masalah, yaitu proses penyelesaian masalah secara langsung dan meminta maaf secara adat dengan memberikan pinang maupun piring. Namun, ada juga partisipan perempuan yang memilih untuk tidak membantu keluarga, marah terhadap diri sendiri, menyalahkan orang lain terhadap masalah yang dihadapinya dengan alasan bahwa itu adalah jalan yang terbaik baginya. Meskipun demikian ada juga partisipan yang menganggap bahwa menyalahkan orang lain atas masalahnya merupakan tindakan yang tidak manusiawi.

Untuk partisipan laki-laki, mereka cenderung menggunakan koping yang berfokus pada emosi. Hal-hal yang dilakukan yaitu; duduk di para-para sambil makan pinang, bercerita dan bercanda, merokok dan minum kopi bersama, menokok sagu (proses pembuatan tepung sagu), pergi ke pantai, dan saling meminta maaf.

\section{Saran}

Penelitian ini memiliki keterbatasan secara metodologis. Selanjutnya, jumlah variabel sosiodemografi perlu dikaji lebih mendalam dan detail lagi sehingga hasil penelitiannya dapat memberikan hasil yang lebih komprehensif.

\section{DAFTAR PUSTAKA}

A. King, Laura. 2010. Psikologi Umum. Jakarta : Salemba Humanika.

Adi, N., Wibawa, K., Widiasavitri, N., Psi, S., \& Psi, M. (2013). Hubungan Antara Gaya Hidup Sehat dengan Tingkat Stres Siswa Kelas XII SMA 
Negeri di Denpasar Menjelang Ujian Nasional Berdasarkan Strategi Coping Stres. Jurnal Psikologi Udayana, 1(1), 138-150.

Bachri, B. S. (2010). Meyakinkan Validitas Data Melalui Triangulasi Pada Penelitian Kualitatif. Teknologi Pendidikan, 10(1), 46-62.

Badan Penelitian dan Pengembangan Kesehatan. (2013). Riset Kesehatan Dasar (RISKESDAS) 2013. Laporan Nasional 2013, 1-384. https://doi.org/1 Desember 2013

Badan Penelitian dan Pengembangan Kesehatan. (2018). Hasil Utama RISKESDAS 2018.

Bakhtiar, \& Asriani. (2015). Efektivitas Strategi Problem Focused Coping dan Emotion Focused coping Dalam Meningkatkan Pengelolaan Stres Siswa di SMA negeri 1 Barru. Guidena/Jurnal Ilmu Pendidikan, Psikologi, Bimbingan Dan Konseling, 5 No 2(2088-9623), 69-82.

Dharmawan Triadib. (2015). Musik Klasik dan Daya Ingat Jangka Pendek Pada Remaja. Jurnal Ilmiah Psikologi Terapan, 03(02), 370-382. http://ejournal.umm.ac.id/index.php/jipt/article/view/3538

Dumatubun, A. (2002). Kebudayaan, Kesehatan Orang Papua Dalam Perspektif Antropologi Kesehatan. Jurnal Antropologi Papua, 1(1), 94-95.

Hamdi, Muluk, \& Muniarti, J. (2007). Konsep Kesehatan Mental Menurut Masyarakat Etnik Jawa dan Minangkabau. Konsep Kesehatan Mental, 13(2), 167-181.

Idaiani, Kristanto, \& Antonius Yudi. (2009). Analisis Gejala Gangguan Mental Emosional Penduduk Indonesia. Majalah Kedokteran Indonesia, 59(10), 473-479.

Mansoben. (2003). Sistem Politik Tradisional Etnis Byak Kajian Tentang Pemerintah Tradisional. Antropologi Papua, 1(3), 20.

Mongisidi, R., Tumewah, R., \& Kembuan, M. A. H. . (2012). Profil Penurunan Fungsi Kognitif Pada Lansia Di Yayasan-Yayasan Manula Di Kecamatan Kawangkoan.

Nurhayati, S. R. (2014). Peningkatan Kemampuan Menggunakan Problem Focused Coping Perempuan Korban Kekerasan Dalam Rumah Tangga. Ilmu Pendidikan, 1-21.

Oktarisa, \& Yusra. (2015). Perbedaan Prestasi Akademik Ditinjau Dari Coping Stress dan Jenis Kelamin Pada Pers Mahasiswa. Jurnal RAP UNP, 6(2), 136- 
145.

Putri, A. W., Wibhawa, B., \& Gutama, A. S. (2012). Kesehatan Mental Masyarakat Indonesia ( Pengetahuan , Dan Keterbukaan Masyarakat Terhadap Gangguan Kesehatan Mental ). Prosiding KS: Riset \& PKM, 2(2), $252-258$.

Rayanti, R. E., Wariunsora, N. S., \& Soegijono, S. P. (2019). The Psychosocial Responses and Coping Strategies of Diabetes Mellitus Type 2 Patients of The Ambon Culture Dengan Budaya Ambon. Masyarakat Kebudayaan Politik, 31(4), 389-399. https://ejournal.unair.ac.id/MKP/article/view/8655/6254

Saputra, F. A., Ranimpi, Y. Y., \& Pilakoannu, T. (2018). Kesehatan Mental dan Koping Strategi di Kudangan, Kecamatan Delang, Kabupaten Lamandau Kalimantan Tengah : Suatu Studi Sosiodemografi. Humanitas, 2(1), 63-74.

Silaen, A. C., \& Dewi, K. S. (2015). Hubungan Antara Regulasi Emosi Dengan Asertivitas (Studi Korelasi Pada Siswa Di SMA Negeri 9 Semarang). Jurnal Empati, 4(April), $175-181$. https://ejournal3.undip.ac.id/index.php/empati/article/view/14912/14427

Siti, M. (2017). Strategi Coping: Teori Dan Sumberdayanya. Jurnal Konseling Andi Matappa, 1 No 2(p:ISSN: 2549-1857; e-ISSN: 2549-4279), 101-107.

Suardana. (2011). Hubungan Faktor Sosiodemografi, Dukungan Sosial dan Status Kesehatan Dengan Tingkat Depresi Pada Agregat Lanjut Usia di Kecamatan Karangasem, Kabupaten Karangasem Bali.

Tri, W. J. (2012). Stres dan Strategi Coping Pada Siswa yang Tidak Lulus Ujian Nasional. Psikopedagogia, 1(2).

Sugiono. (2016). Memahami Penelitian Kualitatif. CV. Alfabeta. Bandung.

Suardiman SP. (2011). Psikologi Usia Lanjut. Gadjah Mada University Press. Yogyakarta.

Sunaryo. (2004). Psikologi untuk keperawatan. Buku kedokteran EGC: Jakarta

Walgito B. (1986). Pengantar Psikologi Umum. Fakultas Psikologi UGM: Yogyakarta 